\title{
ONLINE INFORMATION SEARCHING STRATEGIES OF OPEN AND DISTANCE LEARNERS: ANADOLU UNIVERSITY SAMPLE
}

Dr. Berrin OZKANAL

ORCID: 0000-0002-9506-6082

Open Education Faculty

Anadolu University

Eskisehir, TURKEY

Dr. Secil KAYA GULEN

ORCID: 0000-0002-8680-9980

Faculty of Open Education

Anadolu University

Eskisehir, TURKEY

Dr. E. Pinar UCA GUNES

ORCID: 0000-0003-1750-1998

Open and Distance Education Application and Research Center

Eskisehir Technical University

Eskisehir, TURKEY

Received: 20/10/2020 Accepted: 23/12/2020

\begin{abstract}
Although there are questions about the validity, reliability and accuracy of the information on the internet, Internet is an important tool to enrich students' learning habits and experiences. It is emphasized that individuals should have advanced strategies for searching online information. These strategies have critical importance especially in the field of open and distance learning. This study aims to determine the online information searching strategies of open and distance learners. "Online Information Searching Inventory" developed by Tsai (2009) was used for data collection. The population consists of 925.058 students enrolled in Anadolu University Open Education System in the 2017-2018 academic year. The research sample consists of 3.357 students who voluntarily responded questionnaire. Determining whether these strategies differ according to gender, age and enrollment type constitute the sub-objectives of the study. When examining these strategies according to gender variable, t-test was used; then One-way ANOVA analysis was used for age and enrollment type variables. Finally, it is seen that there are significant differences between online information searching strategies and age, gender, enrollment type. The age and enrollment type are taken in the consideration within the scope of experience and it is seen that the experience is more decisive than the gender for open and distance learners.
\end{abstract}

Keywords: Online information searching strategies, open and distance learning, university students.

\section{INTRODUCTION}

Today, the development and spread of information and communication technologies has contributed to the diversification of information access. Internet has become the primary source of information by ensuring information accessible and editable by everyone (Askar and Mazman, 2013). According to Boldt, Gustafson and Johnson (1995), although there are questions about the validity, reliability and accuracy of the information accessed on the internet; Internet is an important tool that can be used to enrich students' learning habits and experiences. It offers a variety of advantages such as providing rich and flexible learning 
environments, providing cheap and easy access to information, and using different environments such as animation, video, sound and text. Nevertheless, it is almost impossible to control or monitor what is being published. Yolal and Kozak (2008) touched upon the difficulties encountered in reaching accurate and useful information, and expressed their concerns about the reliability of the information provided on the web. The development of Web 2.0 technologies has raised concerns about the validity and reliability of online information. In particular, Web 2.0's ability to change the information on the Internet has made the quality and adequacy of information more questionable. In this regard, Debowski (2001) stated that it is a difficult and complex process to use the Internet for information search purposes and emphasized that individuals should have advanced strategies for searching online information.

Online information search is defined as a complex process involving a series of cognitive and metacognitive strategies (Hofer, 2004; Tsai and Tsai, 2003; Cevik, 2015). Tsai (2003) examined students' online information searching processes in depth and mentioned that individuals have three main areas: behavioral, procedural and metacognitive. The behavioral domain includes control and routing strategies that define internet searching applications and navigation skills throughout the search process. The procedural area consists of trial-and-error and problem-solving strategies that include different search approaches and the ability to overcome problems in the search process. Finally, the metacognitive field includes the basic skills and strategies necessary for goal-oriented thinking, monitoring the search process, identifying key information, and interpreting and evaluating information (Cevik, 2015, p.54). Tsai (2009) also mentions seven different strategies for these three areas. These strategies: Control, Disorientation; Trial and Error, Problem Solving, Purposeful Thinking, Select Main Ideas and Evaluation. A diagram showing main key areas and the online information searching strategies is given in Figure 1.

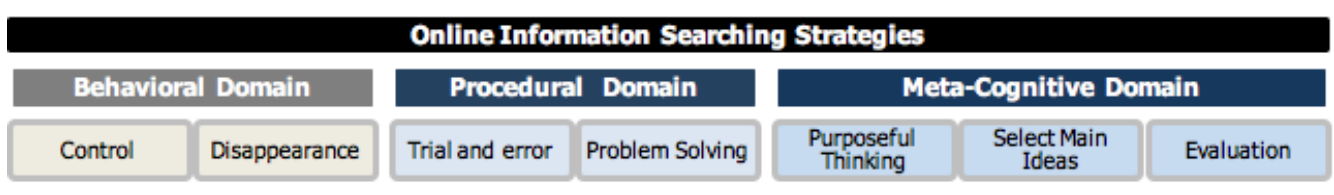

Figure 1. Online Information Searching Strategies

These online information-searching strategies have critical importance in the field of education, especially in open and distance learning where the internet is considered as an effective and essential tool. For individuals who take responsibility for learning in open and distance learning, the Internet is both a learning resource and a communication/ interaction mean. The right use of the Internet provides students great advantages. Wu and Tsai (2005) suggest that students' online search strategies in open and distance learning process are one of the most important factors affect student performance. Similarly, Wagner (2008) states that one of the most important skills that 21st-century students will need is choosing the right information that can provide personal benefit or find solutions to their own problem; also making connections between the information and making inferences. In this context, it is important for open and distance learners to benefit from information searching strategies in reaching and using accurate and reliable information. Here, finding the information needed and analyzing them means information literacy. In this sense, information literacy is defined as "access to information" and "the ability to use information effectively" (ALA, 1989). It is possible to say that the correct beginning for each skill -information access, information analysis and information literacy- is the effective use of information searching strategies. Individuals who use such information searching strategies effectively will have access to accurate and useful information and will be able to analyze this information and work within the scope of information literacy.

\section{PURPOSE OF THE STUDY}

The aim of this study is to determine online information searching strategies of students at Anadolu University Open Education System. Determining whether these strategies differ according to gender, age and enrollment type constitute the sub-objectives of the study. The following questions are have been sought to answer: 
- What information searching strategies do open and distance learners use?

- Do the information searching strategies differ significantly according to the gender of the students?

- Do the information searching strategies differ significantly according to the age of the students?

- Do the information searching strategies differ significantly according to the enrolment type of the students?

Studies that focuses on information searching strategies conducted in formal education in general. However, it is noteworthy that there are limited surveys conducted in the field of open and distance learning. It is thought that information searching strategies of open and distance learners may be different from formal education students. Distance learners interact much more with online contents and have more individual responsibilities in the learning process. Considering differentiated information searching strategies of distance learners can have positive effects on the learning outcomes of ODL. This study has a great importance in terms of contributing to fill this gap in the ODL.

\section{RELATED RESEARCHES}

There is a wide range of research in the literature dealing with information searching strategies. Information searching strategies, which have been taken into consideration in terms of different variables with different sample groups, have become an important research area.

In this area, Meng-Jung Tsai has prominent and varied works. Tsai and Tsai (2003) examined students' information searching strategies in web based learning environments and demonstrated the effect of Internet self-efficacy on information searching strategies. As a result of the study, it was seen that students with high self-efficacy had better and more effective information searching strategies. Wu and Tsai (2005) also found that information-searching strategies were a significant variable in evaluating web materials. In another study conducted by Wu and Tsai (2007), the views of 1220 undergraduate and graduate students using online media in Taiwan were received. As a result of this study, it was found that students' information searching strategies differed significantly according to gender and class level. It was determined that male students use the matching strategy -which is a less sophisticated strategy- more frequently. In addition, it has been determined that graduate students are more oriented towards real resources than undergraduate students are. According to Tsai (2009)'s study related to the information searching strategies in terms of gender and web search experience, there is no difference between male and females in the use of metacognitive strategies. Similarly, he mentioned that there is no correlation between web search experience and metacognitive strategies. However, Kammerer, Bråten, Gerjets and Strømsø (2013) found a positive relationship between students' web search experiences and the status of evaluating the sought information. In other words, experienced web researchers tend to evaluate the reliability of information and choose resources that are more suitable. In another study, Tabatabai and Shore (2005) examined the impact of experience on information searching strategies and found that experience was an important factor in searching information. In addition, Thatcher (2008) (in Turan, Reisoglu, Ozcelik and Goktas, 2015) stated that inexperienced individuals use less procedural and metacognitive strategies than experienced individuals do.

On the other hand, Cevik (2015) points out there are various researches revealing that individual characteristics such as gender and web search experience affect searching strategies. For example, males have better behavioral and procedural strategies than females do (Maghferat \& Stock, 2010; Roy and Chi, 2003; Tsai, 2009). In other words, males can better control Internet search applications and seems to be more successful about navigating within the search results, using different search techniques and solving problems related to searching process. However, Maghferat and Stock (2010) argue that females are searching more extensively and trying to gather information from various sources.

Ay and Seferoglu (2017) also examined graduate students' information searching strategies according to different variables and found that gender, internet experience and computer usage level make a significant difference in online information searching strategies. Caka, Dogan and Sahin (2016), who examined the information searching strategies of social network users, determined that the strategies differ according to age, education level and daily internet usage period. Similarly, the results of the research conducted by the Kurulgan and Argan (2007) also show that gender, academic department and competence level have a statistically significant effect on online information searching strategies. 
It can be seen that the studies conducted in this field vary and focuses on information searching behaviors in general. However, it is noteworthy that there are limited surveys conducted in the field of open and distance learning. It is thought that information search strategies of open and distance learners may be different from formal education students. It should be taken into consideration that considering these differences in design and management of the services offered may also make a difference on the learning outcomes of distance education. In this context, it is expected that this study, aiming to determine information search strategies of open and distance learners, will contribute to the field.

\section{THEORETICAL FRAMEWORK}

Nowadays, the diversification of information access possibilities and the changes in the educational paradigms have made the education learner centered within the framework of the constructivist approach. Arslan (2007) states that theoretical basis of active learning, which places the learner at the center, are based on constructivism and cognitive approach. From a philosophical perspective, Arslan (2007) stated that constructivism is a concept related to epistemology and tries to explain the source of knowledge. He also indicates that accessing way to existing information is an important issue. Constructivism and information searching strategies can be associated in this context.

Arslan (2007) summarized the views of constructivist philosophers as follows: For example, Immanuel Kant supports this idea by saying that people are not passive recipients of information. According to Kant, learners take information actively, associate them with their past knowledge, and add them to their own interpretations. Also Piaget's constructivism is based on cognitive theory, and the basis for learning is discovery. The way in which new information is discovered is important. Bruner's views on learning also shed light on the constructivism approach. According to Bruner, learning is a process in which students base their new concepts on existing knowledge. The learner selects the information, creates the hypothesis and makes decisions in order to integrate the new experiences with the existing mental structures. To summarize, the common point that all thinkers express in different ways is the active role of the individual in accessing or discovering the information. In this context, it will not be wrong to say that access to information is an important subject, which has been emphasized in both the educational and the philosophical terms. In today's world, where information is growing day by day and access routes are varied, access to information strategies is increasingly critical.

In the researches related with the information searching strategies, it is seen that the relationship between the strategy and experience is frequently questioned. It is possible to explain this by emphasizing the tight relationship between making sense in constructivism and experience. Learners are only rearranging their cognitive structures by establishing a relationship between their predecessors and new knowledge/experience. Therefore, their experience with the information searching strategies can affect the results of searching and interpretation processes. Based on the theoretical framework of constructivism, it is appropriate to consider information searching strategies in terms of experience variable. The ages of learners and the types of enrollment can be considered as variables that give insight into experience.

\section{METHODOLOGY}

This research, which aims to determine online information searching strategies of open and distance learners, is designed according to general and relational survey models. Determining whether these strategies differ according to gender, age and enrollment type constitute the sub-objectives of the study. The determination of online information searching strategies is covered in the general survey model; and revealing the relationship between online information searching strategies and the determined variables is considered within the context of relational survey model. In survey models, the subject of the study is tried to be defined as it is in its own conditions. The important thing is to reveal the existing ones without any changing (Karasar, 1994). Because many of the educational problems are identifiable, survey model contributes significantly to the theory and practice in understanding knowledge (Balci, 2001). 


\section{Data Collection Tool and Process}

Quantitative research techniques have been used to achieve the research objectives. In this context, "Online Information Searching Inventory" which was developed by Tsai (2009) and adapted to Turkish by Askar and Mazman (2013) was used as data collection tool. The data collection tool consists of two parts. First part consist of demographic information such as gender, age and enrollment type. In the second part, Inventory of Online Information Search Strategies takes part. It consists of 25 items and 7 factors (disorientation, evaluation, purposeful thinking, differentiation of basic ideas, trial and error, control and problem solving). The cronbach alpha reliability coefficient of the 6-point Likert-type scale was .91. The internal consistency coefficients of the sub-factors were $0.88,0.79,0.79,0.82,0.75,0.74$ and 0.64 , respectively. The lowest score that can be obtained from the scale is 25 and the highest score is 150 . The high score obtained represents advanced online information searching strategies. The high score related to the sub-factors indicates that the strategy for that factor is improved.

The data collection tool was transferred to the electronic platform by using Google Forms. Access given to the questionnaire via student automation system between the dates of 15.12.2017-15.04.2018. The student automation system is a platform that enables students to access the information about their courses and exams.

\section{Population and Research Sample}

The research population consists of 925.058 students (403.005 associate and 522.053 undergraduate students) enrolled in Anadolu University Open Education System in the 2017-2018 academic year. The research sample consists of 3.357 students who voluntarily responded questionnaire published in student automation system. As a result of the controls, 3 questionnaires were found to be invalid and the number of samples was updated as 3.354. The demographic characteristics of the sample group is given in Table 1.

Table 1. Characteristics of Sample Group

\begin{tabular}{lcc}
\hline Enrollment Type & $\mathbf{f}$ & \% \\
\hline SSPE* & 672 & 20,0 \\
Second university & 1711 & 51,0 \\
Vertical transmission & 852 & 25,4 \\
Horizontal transition & 119 & 3,5 \\
\hline Gender & $\mathbf{f}$ & $\%$ \\
\hline Female & 1292 & 38,5 \\
Male & 2062 & 61,5 \\
\hline Age Groups & $\mathbf{f}$ & $\%$ \\
\hline $18-24$ & 1332 & 39,7 \\
$25-30$ & 1037 & 30,9 \\
$31-35$ & 366 & 10,9 \\
$36-40$ & 283 & 8,4 \\
$41 \leq$ & 336 & 10 \\
\hline
\end{tabular}

* Student selection and placement examination

There are different types of registration in the open and distance education system. Students can enroll in the same program with different enrollment types. Even if they go through the same processes and are exposed to the same content, they may have different features as they register according to different criteria. Enabling registration opportunity for different audiences is important in ensuring equality opportunities; however, it brings a heterogeneous student population. For example, a 23-year-old or 40-year-old university graduate and a 17-year-old student who graduated from high school can enroll in the same program at the same period. Students, whose individual characteristics differ, can also differ about the online information searching strategies. In this context, the enrolment type has been accepted as a variable that can make a difference in the research results. 


\section{Data Analyses}

In the analysis of the data, firstly it has been checked whether the data meet the parametric test conditions. In this context, the conditions of providing the assumption of normal distribution are examined. The kurtosis and skewness values of the data were calculated and given in Table 2.

Table 2. Normality Assumption Test Kurtosis and Skewness Values

\begin{tabular}{lcc}
\hline & Skewness & Kurtosis \\
\hline Disorientation & 1,016 &, 674 \\
Evaluation &,- 452 & $-1,085$ \\
Purposeful thinking &,- 435 & $-1,080$ \\
Trial and error &,- 434 & $-1,095$ \\
Basic ideas differentiation &,- 435 & $-1,147$ \\
Control &,- 497 & $-1,084$ \\
Problem solving &,- 279 &,- 640
\end{tabular}

Kline (1998) states that for multivariate normality, the distribution is normal when the kurtosis value is $<2$. When interpreting the kurtosis and skewness, Tabachnick and Fidell (2013) consider $+1.5-1.5$, George and Mallery (2010) consider $+2.0-2.0$ as the starting point. The kurtosis and skewness coefficient are considered differently by different authors, but between -3 and +3 can be considered as normal distribution (Kalayci, 2010). In this study, the coefficients for each sub-factor were between $-3(-2 /-1.5)$ and $+3(+2 /+1.5)$, and this indicates that the data were distributed normally. In this context, it is appropriate to use parametric tests to question the relationship between variables and online information searching strategies. In order to determine whether the information searching strategies differ according to gender, t-test was applied. In addition, One-way ANOVA analysis was applied to determine whether it varies according to age and enrollment type. Following the ANOVA analysis, Post-hoc comparisons were performed to determine which group was the cause of the difference. The data of the study were analyzed by using SPSS program and the significance level was accepted as .05 in all analyzes.

\section{FINDINGS}

\section{Findings for Online Information Searching Strategies Used by Open and Distance Learners}

The usage levels of information searching strategies was determined in accordance with the average scores of sub-factors -such as disorientation, evaluation, purposeful thinking, basic ideas differentiation, trial and error, control and problem solving-. The descriptive findings related to the participants' online information searching strategies are given in Table 3.

Table 3. Descriptive Findings of the Participants' Online Information Searching Strategies

\begin{tabular}{llllll}
\hline Sub-Factors & $\mathrm{N}$ & Minimum & Maximum & Mean & Std. Deviation \\
\hline Disorientation & 3354 & 1,00 & 6,00 & 2,26 & 1,18 \\
Evaluation & 3354 & 1,00 & 6,00 & 4,09 & 1,61 \\
Basic ideas differentiation & 3354 & 1,00 & 6,00 & 4,10 & 1,67 \\
Purposeful thinking & 3354 & 1,00 & 6,00 & 4,07 & 1,61 \\
Problem solving & 3354 & 1,00 & 6,00 & 3,67 & 1,35 \\
Control & 3354 & 1,00 & 6,00 & 4,15 & 1,63 \\
Trial and error & 3354 & 1,00 & 6,00 & 4,12 & 1,63 \\
\hline
\end{tabular}


When the descriptive values in Table 3 are analyzed, the highest average represents the most adopted strategy. In this context, the averages of "disorientation strategy" are low; the mean of the "control strategy" appears to be at high level. Then, the averages for evaluation, purposeful thinking, trial-and-error, basic ideas differentiation and problem-solving strategies are at the middle level.

\section{Relationship between Online Information Searching Strategies of Distance Learners and Age Groups}

One-way ANOVA was applied to determine whether the average scores of factors related to online information searching strategies differ significantly according to the ages. Table 4 shows the results of the ANOVA analysis.

Table 4. Relationship between Online Information Searching Strategies and Age Groups

\begin{tabular}{|c|c|c|c|c|c|c|c|c|c|}
\hline & $\begin{array}{l}\text { Age } \\
\text { Group }\end{array}$ & $\mathrm{N}$ & $X$ & $\mathrm{Sd}$ & $\mathrm{F}$ & p & $\begin{array}{c}\text { Test of } \\
\text { Homogeneity of } \\
\text { Variances (Sig.) }\end{array}$ & & \\
\hline \multirow{5}{*}{ Disorientation } & $18-24$ & 1332 & 2,2789 & 1,21261 & \multirow{5}{*}{1,713} & \multirow{5}{*}{144} & \multirow{5}{*}{,358 } & & \multirow{5}{*}{$\ldots$} \\
\hline & $25-30$ & 1037 & 2,2565 & 1,16497 & & & & & \\
\hline & $31-35$ & 366 & 2,1250 & 1,17257 & & & & & \\
\hline & $36-40$ & 283 & 2,3207 & 1,21451 & & & & & \\
\hline & $41 \leq$ & 336 & 2,3274 & 1,16316 & & & & & \\
\hline \multirow{5}{*}{ Evaluation } & $18-24$ & 1332 & 4,0049 & 1,63415 & \multirow{5}{*}{5,972} & \multirow{5}{*}{, $000^{*}$} & \multirow{5}{*}{, $008^{*}$} & & \multirow{5}{*}{$\begin{array}{l}18-24 \\
25-30\end{array}$} \\
\hline & $25-30$ & 1037 & 4,0521 & 1,60809 & & & & $36-40$ & \\
\hline & $31-35$ & 366 & 4,1633 & 1,67899 & & & & $30-40$ & \\
\hline & $36-40$ & 283 & 4,4788 & 1,49719 & & & & & \\
\hline & $41 \leq$ & 336 & 4,2292 & 1,55830 & & & & & \\
\hline \multirow{5}{*}{$\begin{array}{l}\text { Purposeful } \\
\text { thinking }\end{array}$} & $18-24$ & 1332 & 3,9747 & 1,64191 & \multirow{5}{*}{7,107} & \multirow{5}{*}{, $000^{*}$} & \multirow{5}{*}{, $000 *$} & \multirow{5}{*}{$36-40$} & \multirow[b]{2}{*}{$18-24$} \\
\hline & $25-30$ & 1037 & 4,0258 & 1,61298 & & & & & \\
\hline & $31-35$ & 366 & 4,1141 & 1,65939 & & & & & $25-30$ \\
\hline & $36-40$ & 283 & 4,5018 & 1,46441 & & & & & $31-35$ \\
\hline & $41 \leq$ & 336 & 4,2039 & 1,52250 & & & & & \\
\hline \multirow[t]{5}{*}{ Trail and Error } & $18-24$ & 1332 & 4,0100 & 1,65344 & \multirow{5}{*}{6,530} & \multirow{5}{*}{, $000^{*}$} & \multirow{5}{*}{, $000^{*}$} & \multirow{3}{*}{$36-40$} & \\
\hline & $25-30$ & 1037 & 4,1041 & 1,62023 & & & & & $18-24$ \\
\hline & $31-35$ & 366 & 4,1612 & 1,73349 & & & & & $25-30$ \\
\hline & $36-40$ & 283 & 4,5135 & 1,50495 & & & & \multirow[t]{2}{*}{$41 \leq$} & \multirow[t]{2}{*}{$18-24$} \\
\hline & $41 \leq$ & 336 & 4,2808 & 1,55119 & & & & & \\
\hline \multirow{5}{*}{$\begin{array}{c}\text { Basic Ideas } \\
\text { Differencation }\end{array}$} & $18-24$ & 1332 & 4,0118 & 1,71062 & \multirow{5}{*}{5,553} & \multirow{5}{*}{, $000^{*}$} & & & \\
\hline & $25-30$ & 1037 & 4,0598 & 1,66385 & & & & $36-40$ & $18-24$ \\
\hline & $31-35$ & 366 & 4,1157 & 1,77475 & & &, $000 *$ & & $25-30$ \\
\hline & $36-40$ & 283 & 4,4817 & 1,48301 & & & & & $31-35$ \\
\hline & $41 \leq$ & 336 & 4,2609 & 1,56825 & & & & & \\
\hline Control & $18-24$ & 1332 & 4,0672 & 1,65743 & & & & & \\
\hline & $25-30$ & 1037 & 4,1097 & 1,63142 & & & & $36-40$ & $18-24$ \\
\hline & $31-35$ & 366 & 4,2398 & 1,71158 & 5,083 &, $000 *$ &, $000 *$ & $30-40$ & $18-24$ \\
\hline & $36-40$ & 283 & 4,5097 & 1,50108 & & & & & $25-30$ \\
\hline & $41 \leq$ & 336 & 4,2597 & 1,57182 & & & & & \\
\hline Problem solving & $18-24$ & 1332 & 3,6126 & 1,38556 & & & & & \\
\hline & $25-30$ & 1037 & 3,6397 & 1,35144 & & & & $36-40$ & $18-24$ \\
\hline & $31-35$ & 366 & 3,6785 & 1,38952 & 6,123 &, $000^{*}$ &, $000 *$ & & $25-30$ \\
\hline & $36-40$ & 283 & 4,0294 & 1,26584 & & & & & $31-35$ \\
\hline & $41 \leq$ & 336 & 3,7669 & 1,25182 & & & & & \\
\hline
\end{tabular}


When the level of online information searching strategies are examined according to the age variable, it is seen that the highest average belongs to the $36-40$ age range, for evaluation $(X=4,4788)$, purposive thinking $(X=4,5018)$, trial-and-error $(X=4,5135)$, basic ideas differencation $(X=4,4817)$, control $(X=4,5097)$ and problem solving $(X=4,0294)$ strategies. In addition, the lowest averages belong to the 18-24 age range in all strategies.

Table 4 shows that, except the disorientation strategy, there is a statistically significant difference between the age of participants and their searching strategies $(\mathrm{p}=, 000<0.05)$. In order to find out which groups this variance was caused by, the Tamhane T2 Post-Hoc test was applied for the online information searching strategies whose variances were found to be not homogeneous -evaluation, purposeful thinking, trial and error, basic ideas, control, problem solving- $(\mathrm{p}=, 014 /, 000<0.05)$. Since the sig value for the disorientation strategy is greater than 0.05 , the post-hoc test has not been performed.

According to the results of the Tamhane test, it was determined that there was a significant relationship between the 36-40 age range and 18-24/25-30 ages for all information searching strategies ( $\mathrm{p}<0.05)$. Table 4 shows that 36-40 age range students have higher levels of disorientation, evaluation, purposeful thinking, trial and error, basic ideas differentiation, control, problem solving strategies than students aged 18-24 and 25-30. There is also a meaningful relationship between 36-40 and 31-35 age groups in the strategies of purposeful thinking, differentiating basic ideas and problem solving. Parallel to the above-mentioned relationship, it is understood that the use of these strategies in the 36-40 age group is higher than the 31-35 age group. On the other hand, a significant difference was observed among the age range of 41 years and over and 18-24 about the level of using the trial and error strategy. As a result, it is observed that as the students' ages increase, the level of using online information searching strategies also increases.

\section{Relationship between Online Information Searching Strategies of Distance Learners and Gender}

One-sample t=test was applied to determine whether the average scores of factors related to online information searching strategies differ significantly according to the gender. Table 5 shows the results of the t-test analysis.

Table 5. Relationship between Online Information Searching Strategies and Gender

\begin{tabular}{|c|c|c|c|c|c|c|c|}
\hline \multirow[t]{2}{*}{ Strategies } & \multicolumn{4}{|c|}{ Group Statistics } & \multicolumn{2}{|c|}{$\begin{array}{c}\text { Levene's Test for Equality } \\
\text { of Variances }\end{array}$} & \multirow{2}{*}{$\begin{array}{c}\text { t-test } \\
\text { Sig. (2-tailed) }\end{array}$} \\
\hline & Gender & $\mathbf{N}$ & $\mathbf{x}$ & Sd & $\mathbf{t}$ & Sig. & \\
\hline \multirow[t]{2}{*}{ Disorientation } & Female & 1292 & 2,1151 & 1,09256 & & & \\
\hline & Male & 2062 & 2,3566 & 1,23756 & 17,500 &, $000^{*}$ &, $000^{* *}$ \\
\hline \multirow{2}{*}{ Evaluation } & Female & 1292 & 4,0209 & 1,64775 & & & \\
\hline & Male & 2062 & 4,1483 & 1,59633 & 5,576 &, $018^{*}$ &, $026^{* *}$ \\
\hline \multirow[t]{2}{*}{ Purposeful thinking } & Female & 1292 & 3,9807 & 1,64933 & & & \\
\hline & Male & 2062 & 4,1311 & 1,59049 & 6,971 &, $008^{*}$ &, $009^{* *}$ \\
\hline \multirow[t]{2}{*}{ Trial and error } & Female & 1292 & 4,0431 & 1,66497 & & & \\
\hline & Male & 2062 & 4,1767 & 1,61513 & 5,935 &, $015^{*}$ &, $021^{* *}$ \\
\hline \multirow[t]{2}{*}{ Basic ideas differentiation } & Female & 1292 & 4,0137 & 1,70878 & & & \\
\hline & Male & 2062 & 4,1583 & 1,65314 & 4,117 &, $043^{*}$ &, $015^{* *}$ \\
\hline \multirow[t]{2}{*}{ Control } & Female & 1292 & 4,0430 & 1,66574 & & & \\
\hline & Male & 2062 & 4,2265 & 1,61739 & 5,743 &, $017^{*}$ &, $002^{* *}$ \\
\hline \multirow[t]{2}{*}{ Problem solving } & Female & 1292 & 3,5841 & 1,37499 & & & \\
\hline & Male & 2062 & 3,7381 & 1,34243 & 4,654 &, $031^{*}$ &, $001^{* *}$ \\
\hline
\end{tabular}

\footnotetext{
${ }^{*} \mathrm{p}<.05$ variances are homogeneous ${ }^{* *}$ Sig. (2-tailed) indicates whether there is a difference between the groups.
} 
According to these results, the homogeneity of the variance was tested by Levene test; and variances were found to be homogeneous. ( $\mathrm{p}<.05)$. Sig. (2-tailed) is the value that indicates whether there is a difference between the groups by gender. Sig.(2-tailed) values less than 0.05 for all strategies indicate a significant difference between the groups. In this context, when the averages of the groups are compared, it is noteworthy that the averages of males in all categories are higher.

\section{Relationship between Online Information Searching Strategies of Distance Learners and Enrollment Type}

One-way ANOVA was applied to determine whether the average scores of factors related to online information searching strategies differ significantly according to the enrollment type. Table 6 shows the results of the ANOVA analysis. When the level of online information searching strategies levels are examined according to the enrollment type, except disorientation strategy, it is seen that the highest average belongs to the second university for evaluation $(X=4,2288)$, purposive thinking $(X=4,1563)$, trial-and-error $(X=4,2145)$, basic ideas differentiation $(X=4,2032)$, control $(X=4,2526)$ and problem solving $(X=3,7276)$ strategies. In addition, the lowest averages belong to the vertical transmission in evaluation $(X=3,9187)$, purposeful thinking $(X=3,9366)$, trial and error $(X=3,9980)$, basic ideas differentiation $(X=3,9425)$, and control $(\mathrm{X}=4,0241)$ strategies. Unlike the others, the highest average in the disorientation category belongs to the horizontal transition $(X=2,4706)$ and the lowest average belongs to the second university $(X=2,1929)$.

Table 6. Relationship between Online Information Searching Strategies and Enrollment Type

\begin{tabular}{|c|c|c|c|c|c|c|c|c|}
\hline Strategies & Enrollment Type & $\mathbf{N}$ & $\mathbf{X}$ & Sd & $\mathbf{F}$ & $\mathbf{p}$ & $\begin{array}{c}\text { Test of } \\
\text { Homogeneity } \\
\text { of Variances } \\
\text { (Sig.) }\end{array}$ & \\
\hline \multirow[t]{4}{*}{ Disorientation } & SSPE* $^{*}$ & 672 & 2,2969 & 1,21621 & \multirow{4}{*}{4,921} & \multirow{4}{*}{, $002^{*}$} & \multirow{4}{*}{, $002^{*}$} & \multirow{4}{*}{$\begin{array}{r}\text { Second } \\
\text { university- } \\
\text { Vertical } \\
\text { transmission }\end{array}$} \\
\hline & Second university & 1711 & 2,1929 & 1,13032 & & & & \\
\hline & $\begin{array}{l}\text { Vertical } \\
\text { transmission }\end{array}$ & 852 & 2,3504 & 1,27074 & & & & \\
\hline & $\begin{array}{l}\text { Horizontal } \\
\text { transition }\end{array}$ & 119 & 2,4706 & 1,20608 & & & & \\
\hline \multirow[t]{4}{*}{ Evaluation } & SSPE & 672 & 4,0186 & 1,64274 & \multirow{4}{*}{8,010} & \multirow{4}{*}{, $000^{*}$} & \multirow{4}{*}{, $003^{*}$} & \multirow{4}{*}{$\begin{array}{r}\text { Second } \\
\text { university- } \\
\text { SSPE / Vertical } \\
\text { transmission }\end{array}$} \\
\hline & Second university & 1711 & 4,2288 & 1,57041 & & & & \\
\hline & $\begin{array}{l}\text { Vertical } \\
\text { transmission }\end{array}$ & 852 & 3,9187 & 1,67376 & & & & \\
\hline & $\begin{array}{l}\text { Horizontal } \\
\text { transition }\end{array}$ & 119 & 3,9832 & 1,58272 & & & & \\
\hline \multirow{4}{*}{$\begin{array}{l}\text { Purposeful } \\
\text { thinking }\end{array}$} & SSPE & 672 & 4,0554 & 1,64647 & \multirow{4}{*}{3,797} & \multirow{4}{*}{, $010^{*}$} & \multirow{4}{*}{, $000 *$} & \multirow{4}{*}{$\begin{array}{r}\text { Second } \\
\text { university- } \\
\text { Vertical } \\
\text { transmission }\end{array}$} \\
\hline & Second university & 1711 & 4,1563 & 1,55868 & & & & \\
\hline & $\begin{array}{l}\text { Vertical } \\
\text { transmission }\end{array}$ & 852 & 3,9366 & 1,69110 & & & & \\
\hline & $\begin{array}{l}\text { Horizontal } \\
\text { transition }\end{array}$ & 119 & 3,9538 & 1,61231 & & & & \\
\hline \multirow[t]{4}{*}{ Trial and error } & SSPE & 672 & 4,0635 & 1,67255 & \multirow{4}{*}{3,753} & \multirow{4}{*}{,010 } & \multirow{4}{*}{, $019 *$} & \multirow{4}{*}{$\begin{array}{r}\text { Second } \\
\text { university- } \\
\text { Vertical } \\
\text { transmission }\end{array}$} \\
\hline & Second university & 1711 & 4,2145 & 1,58843 & & & & \\
\hline & $\begin{array}{l}\text { Vertical } \\
\text { transmission }\end{array}$ & 852 & 3,9980 & 1,68668 & & & & \\
\hline & $\begin{array}{l}\text { Horizontal } \\
\text { transition }\end{array}$ & 119 & 4,1008 & 1,66415 & & & & \\
\hline \multirow{4}{*}{$\begin{array}{l}\text { Basic ideas } \\
\text { differentiation }\end{array}$} & SSPE & 672 & 4,0709 & 1,68826 & \multirow{4}{*}{4,955} & \multirow{4}{*}{, $002^{*}$} & \multirow{4}{*}{, $001^{*}$} & \multirow{4}{*}{$\begin{array}{r}\text { Second } \\
\text { university- } \\
\text { Vertical } \\
\text { transmission }\end{array}$} \\
\hline & Second university & 1711 & 4,2032 & 1,62628 & & & & \\
\hline & $\begin{array}{l}\text { Vertical } \\
\text { transmission }\end{array}$ & 852 & 3,9425 & 1,75372 & & & & \\
\hline & $\begin{array}{l}\text { Horizontal } \\
\text { transition }\end{array}$ & 119 & 3,9804 & 1,65891 & & & & \\
\hline
\end{tabular}




\begin{tabular}{|c|c|c|c|c|c|c|c|c|}
\hline \multirow[t]{4}{*}{ Control } & SSPE & 672 & 4,0863 & 1,67957 & \multirow{4}{*}{4,292} & \multirow{4}{*}{, $005^{*}$} & \multirow{4}{*}{, $000^{*}$} & \multirow{4}{*}{$\begin{array}{r}\text { Second } \\
\text { university- } \\
\text { Vertical } \\
\text { transmission }\end{array}$} \\
\hline & Second university & 1711 & 4,2526 & 1,57530 & & & & \\
\hline & $\begin{array}{l}\text { Vertical } \\
\text { transmission }\end{array}$ & 852 & 4,0241 & 1,71295 & & & & \\
\hline & $\begin{array}{l}\text { Horizontal } \\
\text { transition }\end{array}$ & 119 & 4,0987 & 1,67870 & & & & \\
\hline \multirow[t]{4}{*}{ Problem solving } & SSPE & 672 & 3,6781 & 1,41949 & \multirow{4}{*}{2,029} & \multirow{4}{*}{108} & \multirow{4}{*}{, $000^{*}$} & \\
\hline & Second university & 1711 & 3,7276 & 1,28210 & & & & \\
\hline & $\begin{array}{l}\text { Vertical } \\
\text { transmission }\end{array}$ & 852 & 3,5935 & 1,43547 & & & & \\
\hline & $\begin{array}{l}\text { Horizontal } \\
\text { transition }\end{array}$ & 119 & 3,5910 & 1,44415 & & & & \\
\hline
\end{tabular}

* Student selection and placement examination

Table 6 shows that, except the problem solving strategy, there is a statistically significant difference between the enrollment type and their searching strategies $(\mathrm{p}=, 000<0.05)$. In order to find out which groups this variance was caused by, the Tamhane T2 Post-Hoc test was applied for all online information searching strategies whose variances were found to be not homogeneous. Since the sig value for the program solving strategy $(\mathrm{p}=, 108)$ is greater than 0.05 , the post-hoc test has not been performed for this strategy.

According to the results of the Tamhane test, it was determined that there was a significant relationship between second university and vertical transmission for all information searching strategies. Table 6 shows that students enrolled in the second university have higher levels of evaluation, purposeful thinking, trial and error, basic ideas differentiation, control strategies than students enrolled in vertical transmission. There is also a meaningful relationship between second university and SSPE in the evaluation strategy.

\section{DISCUSSION, CONCLUSION AND SUGGESTIONS}

When students' online information searching processes are considered within the behavioral, procedural and metacognitive domains, both the highest and the lowest averages were observed in the behavioral domain. Procedural and metacognitive domains were observed in medium average. Considering the relationship between online information search strategies and age variable, it was revealed that the behavioral, procedural and mega-cognitive domain skills of the 36-40 age group were more than the other groups. This may be related to the fact that students in the 36-40 age group may have enrolled in the second university. The students in this group are more experienced in educational processes and more open-minded in personal development. Therefore, it is normal for them to be better equipped in online information searching strategies and development areas. These findings support the studies that question the relationship between age / experience and information searching strategies in the literature. Ay and Seferoglu (2017); Caka, Dogan and Sahin (2016) and Kurulgan and Argan (2007) found that experience/competence in internet or computer usage make a significant difference in online information searching strategies.

There is also a significant difference between the groups by gender for all strategies. This is parallel to Wu and Tsai (2007)'s study. In this context, the averages of males in all categories are higher. Therefore, it can be said that men use all the online information-searching strategies more effectively than femles do. In other words, males's behavioral, procedural and metacognitive skills are more developed than females. Cevik (2015) also mentions various researches (Maghferat \& Stock, 2010; Roy and Chi, 2003; Tsai, 2009) that men have better behavioral and procedural strategies than females do. Regarding the findings related to the enrollment type, except problem solving strategy, there is statistically significant difference between the enrollment type and searching strategies. In this context, it is seen that the highest means in the procedural and metacognitive domain, where significant relationship is determined, belong to the second university enrollment type. The low average of the second university in the disorientation strategy supports that the students in this category have advanced online information searching strategies. On the other hand, the significant relationship between second university and vertical transmission for all information searching strategies can be explained by the age and qualification difference between two groups. Vertical transfer refers to the transition from associate degree programs to undergraduate programs. Associate degree students can 
register to the system with lower scores. This difference can be taken into account in explaining the difference between the two groups. Also associate degree students' experiences in the education system are also less than the students enrolled in second university. Students enrolled with the second university are individuals who have successfully completed their bachelor degree studies. Therefore, it can be said that they are better equipped. This can be the starting point for explaining the quality difference between the two groups. In other words, the difference between the second university and vertical transition student profiles is an explanatory feature. This inference can be said to be compatible with the findings of Caka, Dogan and Sahin (2016)'s study that it has been observed that students have more advanced search strategies as the education level increase.

When the findings are evaluated in general, it is seen that there are significant differences between online information searching strategies and age, gender, enrollment type. The findings related to gender and experience variables are parallel to other research findings in the literature. The findings regarding the age and type of enrollment are taken in the consideration within the scope of the experience variable. Finally, it is seen that the experience is more decisive than the gender for open and distance learners.

Finally, in order to provide more detailed information about online information searching strategies, it is thought that the interpretation of relation between internet usage purposes/time and strategies will also contribute to the field. Supporting the findings of the studies with qualitative research findings is another suggestion (Karaoglan Yilmaz, F, Kilic Cakmak, E.,2016). In addition, the comparing formal and distance learners in the same institution and determining online information search strategies of the students in the same enrollment or program type are among the topics that can be addressed within the further researches. In particular, information on how individual characteristics affect online information searching strategies is important in terms of organizing existing platforms considering these features and preparing new and realistic applications. As Kabakci, Firat, Izmirli and Kuzu stated, training on Internet searching skills and strategies should be provided to students.

\section{BIODATA and CONTACT ADDRESSES of AUTHORS}

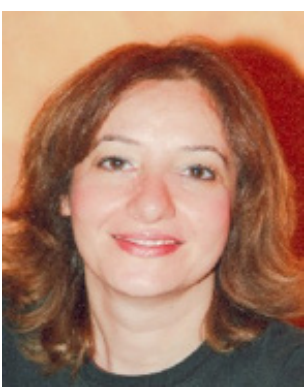

Dr. Berrin OZKANAL is a Assoc. Prof. Dr of Open and Distance Education at Open Education Faculty, Anadolu University. Dr. Ozkanal gained her Ph.D. Public Relations and Publicity at July, 2006. Her academic interest areas are public relations, corporate communication and social network applications, open and distance learning, education futures, public relations and use of information and communications technologies in education. He has over than 8 journal articles published in international indexes, 1 international book chapters and other national and international articles, papers published in international conferences

Berrin OZKANAL

Distance Education Department, Open Education Faculty

Address: Anadolu University, 26470, Tepebasi/Eskisehir, Turkey

Phone: +5366521211

E-mail: bozkanal@anadolu.edu.tr 


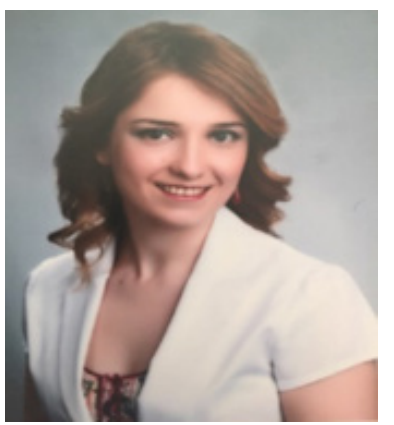

Dr. Secil KAYA GULEN is an Associate Professor of Open and Distance Education at Open Education Faculty, Anadolu University. She completed her M.A. in Educational Technology Department and gained her Ph.D. in Educational Management Supervision and Planning Department in 2011. Study on management of distance education and virtual classrooms within her dissertation. Her academic interest areas are distance education, ICT integration in education, virtual classrooms, adult learning, and instructional technology. She has published many scientific papers, journal articles and book chapters; also she has participated in projects related to distance learning. For 10 years, she was the coordinator of a pre-school teacher-training program in the open education faculty. In addition, she teach in teacher training programs (Faculty of Education) and also in distance education graduate program (Open Education Faculty).

\section{Secil KAYA GULEN}

Department of Distance Education, Faculty of Open Education

Adress: Anadolu University, Yunus Emre Campus, Tepebasi, Eskisehir, TURKEY

Phone: +902223350580

E-mail: secilk@anadolu.edu.tr

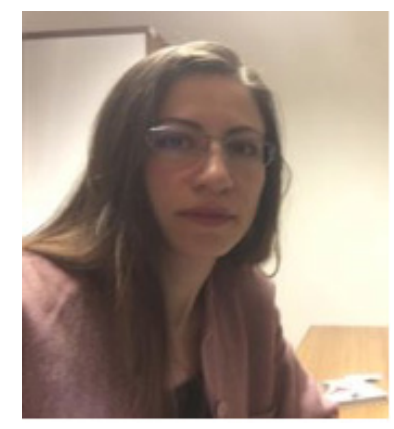

Dr. E. Pinar UCA GUNES is an Associate Professor of Open and Distance Education at Open and Distance Education Application and Research Center, Eskisehir Technical University. Dr. Uca Gunes, is a graduate of Eskisehir Osmangazi University, Department of Industrial Engineering. She completed her master's degrees in Informatics at Anadolu University and Operations Research in Eskisehir Osmangazi University. She gained her Ph.D. in Distance Education, Anadolu University in 2012. She had worked at Anadolu University Open Education Faculty for 15 years. She has been working as the Director of Open and Distance Education Application and Research Center in Eskisehir Technical University. Her academic interest areas are open and distance education management, designing $\&$ building distance education programs, elearning, instructional design, social network approaches, adult learning and lifelong learning.

\section{E. Pinar UCA GUNES}

Open and Distance Education Application and Research Center

Address: Eskisehir Technical University, Iki Eyll Kampusu 26555, Tepebasi/Eskisehir, TURKEY

Phone: +902223213550

E-mail: epug@eskisehir.edu.tr

\section{REFERENCES}

American Library Association / ALA (1989). Presidential Committee on Information Literacy: Final Report. Retrieved 29.03.2019 from http://www.ala.org/ala/acrl/acrlpubs/whitepapers/presidential.cfm

Arslan, M. (2007). Constructivist Approaches in Education. Ankara University Journal of Faculty of Educational Sciences, 40 (1), 41-61.

Askar, P. \& Mazman, S. G. (2013). Cevrimici Bilgi Arama Stratejileri Envanteri'nin Turkceye Uyarlama Calismasi. Egitim ve Bilim, 38 (168), 167-182.

Ay, K. \& Seferoglu, S.S. (2017). Lisansustu Ogrencilerin Cevrimici Bilgi Arama Stratejilerinin Cesitli Degiskenler Acisindan Incelenmesi. Kastamonu Egitim Dergisi, 25 (1), 51-66.

Balci A, 2001. Sosyal Bilimlerde Arastirma. Ankara: Pegem A Yayincilik. 
Boldt, D. J., Gustafson, L. V., \& Johnson, J. E. (1995). The Internet: A Curriculum Warehouse for Social Studies Teachers, Social Studies (86), 105-116.

Caka, C., Dogan, E \& Sahin. Y.L (2016). Sosyal Ag Kullanan Ogrencilerin Cevrimici Bilgi Arama Stratejilerinin Incelenmesi, Trakya Universitesi Egitim Fakultesi Dergisi, 6(1), 1-13.

Cevik, Y. D. (2015). Predicting College Students' Online Information Searching Strategies Based on Epistemological, Motivational, Decisionrelated, and Demographic Variables. Computers \& Education, 90, 54-63.

Debowski, S. (2001). Wrong Way: Go back! An Exploration of Novice Search Behaviours While Conducting an Information Search. The Electronic Library, 19 (6), 371-382.

George, D., \& Mallery, M. (2010). SPSS for Windows Step by Step: A Simple Guide and Reference 17.0 update (10a Ed.) Boston: Pearson

Hofer, B. K. (2004). Epistemological Understandings as a Metacognitive Process: Thinking Aloud During Online Searching. Educational Psychologist, 39 (1), 43-56.

Kabakci, I., Firat, M., Izmirli, S., Kuzu, E. B. (2010). Opinions of teachers on using Internet searching strategies: An elementary school case in Turkey. Turkish Online Journal of Qualitative Inquiry, $1(1), 49-61$.

Kammerer, Y., Bråten, I., Gerjets, P. \& Strømsø, H. I. (2013). The Role of Internet-Specific Epistemic Beliefs in Laypersons' Source Evaluations and Decisions during Web Search on a Medical Issue. Computers in Human Behavior, 29 (3), 1193-1203.

Karaoglan Yilmaz, F , Kilic Cakmak, E . (2016). Internet-specific epistemological beliefs and online information searching strategies of pre-service teachers: gender and department differences. Participatory Educational Research, 3 (2), 63-80.

Karasar, N. (1994). Bilimsel Arastirma Yontemi. Altinci Basim. Ankara: 3A Arastirma Egitim Danismanlik Ltd.

Kline, R. B. (1998). Principles and Practice of Structural Equation Modeling. New York: Guilford Press.

Kurulgan, M. ve Argan, M. (2007). The Information Search Behaviors of University of Anatolia College Students. Journal of Institute of Social Sciences, 7, 291-304.

Maghferat, P. and Stock, W. G. (2010). Gender-Specific Information Search Behavior. Webology 7(2). Article 80. Retrieved 18.02.2019 from http://www.webology.org/2010/v7n2/a80.html

Roy, M. and Chi, M. T. H. (2003). Gender Differences in Patterns of Searching the Web. Journal of Educational Computing Research, 29(3), 335-348. Retrieved 09.02.2019 from http://dx.doi. org/10.2190/7BR8-VXA0-07A7-

Tabatabai, D. ve Shore, B.M. (2005). How Experts and Novices Search The Web. Library and Information Science, 27 (2), 227-248.

Tsai, M.J and Tsai, C.C (2003). Information Searching Strategies in Web-Based Science Learning: The Role of Internet Self-Efficiency. Innovations in Education and Teaching International, 40 (1), 43-50. Retrieved 27.03.2019 from http://dx.doi.org/ 10.1080/1355800032000038822

Tsai, M.J. (2009). Online Information Searching Strategy Inventory (OISSI): A Quick Version and a Complete Version. Computers \& Education, 53 (2), 473-483. Retrieved 27.03.2019 from http:// dx.doi.org/10.1016/j.compedu.2009.03.006

Turan, Z., Reisoglu, I., Ozcelik, E. ve Goktas, Y. (2015). Wagner, T. (2008). Ogretmenlerin Cevrimici Bilgi Arama Stratejilerinin Farkli Degiskenler Acisindan Incelenmesi. Kastamonu Egitim Dergisi, 23(1), 1-16. Retrieved 18.02.2019 from http://dergipark.gov.tr/kefdergi/issue/22600/241445

Yolal, M. and Kozak, R. (2008). The Approach of Students towards Internet for Accessing Information. Journal of Social Sciences, 20, 116-128. 
Wagner, T. (2008). The global achievement gap: Why even our best schools don't teach the new survival skills our children need — and what we can do about it. New York, NY: Basic Books. Retrieved 25.03.2019 from https://pdfs.semanticscholar.org/f961/5da131df0b441ce6307241d82d2b2d2ee162.pdf?_ $\mathrm{ga}=2.70800976 .1135194393 .1587990139-315892198.1587990139$

Wu, Y.T. and Tsai, C.C. (2005). Information Commitments: Evaluative Standards and Information Searching Strategies in Web-Based Learning Environments. Journal of Computer Assisted Learning, 21, 374-385.

Wu, Y.-T. and Tsai, C.-C. (2007). Developing an Information Commitment Survey for Assessing Students' Web Information Searching Strategies and Evaluative Standards for Web Materials. Educational Technology \& Society, 10 (2), 120-132. 